${ }^{11}$ Meunier PJ, Courpron P, Edouard C, Bernard J, Bringuier J, Vignon G Physiological senile involution and pathological rarefaction of bone. Clin Endocrinol Metab 1973;2:239-56.

12 Meunier PJ, Edouard C, Courpron P, Toussaint F. Morphometric analysis of osteoid in iliac trabecular bone. Methodology: dynamic significance of the osteoid parameters. In: Norman AW, et al, eds. Vitamin $D$ and problems related to uraemic bone disease. New York Walter de Gruyter, 1975:149-55.

13 Parsons JA, Reit B, Robinson CJ. A bioassay for parathyroid hormone using chicks. Endocrinology $1972 ; 92: 454-62$.

${ }^{14}$ Cameron JR, Sorenson J. Measurement of bone mineral in vivo: an improved method. Science $1963 ; 142: 230-2$.

15 West RR, Reed GW. The measurement of bone mineral in vivo by photon beam scanning. Br $\mathcal{F}$ Radiol $1970 ; 43$ :886-93.

${ }^{16}$ Bell GH, Dunbar O, Beck JS. Variations in strength of vertebrae with age and their relation to osteoporosis. Calcif Tissue Res 1967;1:75-86.

17 Boyce BF, Courpron P, Meunier PJ. Amount of bone in osteoporosis and physiological senile osteopenia: comparison of two histomorphometric parameters. Metabolic Bone Disease and Related Research 1978;1: $35-8$.
18 Elsasser U, Hesp R, Klenerman L, Reeve J, Veall N, Wootton R. Deficit of trabecular and cortical bone in the radius in low-turnover osteoporosis. Clin Sci Mol Med 1979;57:22p.

19 Parsons V, Mitchell CJ, Reeve J, Hesp R. The use of sodium fluoride, vitamin $\mathrm{D}$ and calcium supplements in the treatment of patients with axial osteoporosis. Calcif Tissue Res 1977;22, suppl:236-40.

${ }^{20}$ Meunier PJ, Bressot C, Vignon E, et al. Radiological and histological evolution of post-menopausal osteoporosis treated with sodium fluoridevitamin D-calcium. Preliminary results. II CEMO symposium, Geneva Médecine et Hygiène 1978:263-76.

21 Parsons JA, Zanelli JM, Gray D, et al. Double isotope estimates of in testinal calcium absorption in rats: enhancement by parathyroid hormone and 1,25 dihydroxycholecalciferol. Calcif Tissue Res 1977 22, suppl:127-32.

22 Bilezikian JP, Canfield RE, Jacobs TP, et al. Response of $1 \propto, 25$ dihydroxyvitamin $\mathrm{D}_{3}$ to hypocalcemia in human subjects. $N$ Engl $\mathcal{f}$ Med $1978 ; 299: 437-41$.

${ }^{23}$ Frost HM. Tetracycline-based histological analysis of bone remodelling. Calcif Tissue Res 1970;3:211-37.

(Accepted 7 February 1980)

\title{
Effect of propranolol and metoprolol on parathyroid hormone and calcitonin secretions in uraemic patients
}

\author{
B COEVOET, C DESPLAN, J L SEBERT, R MAKDASSI, M ANDREJAK, J D GHEERBRANT, \\ M TOLANI, C CALMETTE, M S MOUKHTAR, A FOURNIER
}

\section{Summary and conclusions}

Nine uraemic patients not being treated by dialysis received intravenous propranolol $1 \mu \mathrm{g} / \mathrm{kg} / \mathrm{min}$ for 85 minutes after a priming dose of $1 \mathrm{mg}$. Fifteen days later, six of them received intravenous metoprolol $1.2 \mu \mathrm{g} / \mathrm{kg} /$ min after a priming dose of $1.2 \mathrm{mg}$. Plasma concentrations of parathyroid hormone (PTH) and calcitonin fell significantly after propranolol but not after metoprolol, whereas no change in plasma concentrations of ionised calcium and phosphate occurred with either drug. Heart rate fell similarly with both drugs.

The fact that propranolol acutely suppressed PTH and calcitonin secretion in uraemic patients indicates that further studies are warranted to assess the long-term effects of the drug on the secretion of these hormones and on renal osteodystrophy. The contrast between the responses to propranolol and metoprolol supports the concept that PTH and calcitonin secretion is modulated through specific beta ${ }_{2}$-receptors.

\footnotetext{
Service de Néphrologie-Hémodialyse, Centre Hospitalier Regional et Universitaire d'Amiens, Amiens, France

B COEVOET, MD, physician

J L SEBERT, MD, physician

R MAKDASSI, MD, physician

$M$ ANDREJAK, MD, physician

A FOURNIER, MD, physician

$\mathrm{J} D$ GHEERBRANT, $M D$, physician

$M$ TOLANI, $M D$, physician

Unité Inserm U113, Paris, France

C CALMETTE, MD, physician

M S MOUKHTAR, MD, physician

C DESPLAN, PHD, scientist
}

\section{Introduction}

Most uraemic patients suffer from two potentially serious complications: hypertension and renal osteodystrophy. In about $20 \%$ of the hypertensive patients the hypertension persists despite ultrafiltration and they need antihypertensive drugs. ${ }^{1}$ Renal osteodystrophy in patients on long-term haemodialysis is caused mainly by osteitis fibrosa secondary to parathyroid hormone (PTH) hypersecretion. ${ }^{2}$ Insufficient secretion of calcitonin has, however, also been incriminated. ${ }^{\text {s }}$

Interactions between $\beta$-adrenergic receptors and secretion of PTH and calcitonin have been shown. For example, in-vitro studies with radioactive hydroxybenzylpindolol ${ }^{4}$ have clearly shown the existence of $\beta$-adrenergic receptors in the parathyroid tissue. Furthermore, the fact that isoprenaline had a greater effect in stimulating $\mathrm{PTH}$ and adenosine monophosphate secretion than epinephrine and epinephrine a greater effect than norepinephrine suggests that these receptors are of $\beta_{2}$ type. Finally, propranolol has been shown to prevent the increase of PTH secretion by catecholamines but not the increase induced by hypocalcaemia. The results of these in-vitro studies have been confirmed by in-vivo studies in animals, ${ }^{5}{ }^{6}$ but studies in man have given inconsistent results. ${ }^{7-12}$

Direct evidence of the interaction of $\beta_{2}$-adrenergic receptors and calcitonin secretion has not been produced, but isoprenaline, epinephrine, and salbutamol have been shown to stimulate calcitonin secretion and propranolol to block it in vitro ${ }^{13}$ and in animals $^{1415}$ and normal men. ${ }^{16}{ }^{17}$ In uraemic patients Heynen et $a l^{17}$ have shown that propranolol can prevent the increase of calcitonin secretion induced by alcohol ingestion.

The data in man are therefore contradictory and concern only propranolol and not the newer cardioselective beta-blockers. Because these newer drugs may offer advantages over nonselective drugs (shorter titration duration, less frequent hypoglycaemia on dialysis, and less bronchoconstriction ${ }^{18}$ ) their use is increasingly being considered in the treatment of hypertension in uraemic men. Since uraemic patients also have a secondary hyperparathyroidism the effects of these two types of betablockers on their PTH and calcitonin secretion may be relevant 
in the choice of antihypertensive treatment. We therefore compared the acute effects of propranolol and metoprolol, a newer cardioselective beta-blocker, on the plasma concentrations of PTH and calcitonin in uraemic men.

\section{Patients and methods}

Nine patients not yet on dialysis were chosen because of the absence of contraindications to beta-blockers (they had no asthma or cardiac failure and their P-R interval was under $0.20 \mathrm{~s}$ and their heart rate over 60 beats $/ \mathrm{min}$ ) and their willingness to co-operate. The mean age of the five men and four women was $29 \pm$ (SD) 10 years and their mean serum creatinine concentration $442 \pm 230 \mu \mathrm{mol} / 1(5 \pm 2.6 \mathrm{mg} /$ $100 \mathrm{ml}$ ). The nature of the nephropathy was a chronic glomerulonephritis in five cases, a congenital interstitial nephropathy in three, and a nephroangiosclerosis in one. The patients had taken no betablockers for at least three weeks. Five of them were hypertensive and four normotensive.

Design of the study-Propranolol was administered intravenously with a priming dose of $1 \mathrm{mg}$ diluted in $20 \mathrm{ml}$ of isotonic glucose and then by continuous perfusion (Harvard pump) at the rate of $1 \mu \mathrm{g} /$ $\mathrm{kg} / \mathrm{min}$ for 85 minutes according to the protocol of Williams. Metoprolol was administered according to the same protocol at a dose that produced the same degree of beta-blockade-1.2 mg for the priming dose and $1.2 \mu \mathrm{g} / \mathrm{kg} / \mathrm{min}$ for the perfusion. The two drugs were given to the same patients 15 days apart. Metoprolol was given to only six patients, always after the propranolol sequence. The patients rested for 15 minutes before the drugs were given and their heart rate was measured during this period. Venous blood samples were taken into vacutainers before and 15,30,60, and 90 minutes after the priming dose for measurement of plasma $\mathrm{pH}$ and concentrations of total and ionised calcium, phosphate, bicarbonate, protein, and immunoreactive PTH and calcitonin. From 15 minutes after the priming dose to 90 minutes the patients were placed under cardiac monitoring and an electrocardiogram was recorded before each blood sampling.

Analytical methods-Plasma concentrations of calcium, phosphate, bicarbonate, and protein were measured with an autoanalyser, $\mathrm{pH}$ with a radiometer $\mathrm{pH}$ meter, and ionised calcium with the flowthrough electrode Orion SS20 (our normal mean is $1.04 \pm 0.7 \mathrm{mmol} / 1$ $\left.(2.08 \pm 0.13 \mathrm{mEq} / 1)^{19}\right)$. PTH was measured by radioimmunoassay using an $\mathrm{N}$ terminal specific antibody. This antibody was obtained in goats immunised with the synthetised PTH fragment 1-34 according to the sequence of Niall. ${ }^{20}$ The upper limit of normal is $0.45 \mu \mathrm{g} / 1$. Calcitonin was measured with the homologous radioimmunoassay of Moukhtar. ${ }^{21}$ The upper limit of normal is $0.70 \mu \mathrm{g} / \mathrm{l}$.

Statistical methods-The significance of the changes during betablocker administration was assessed with the Wilcoxon test for paired data. The two drugs were compared with the Wilcoxon test for non-paired data since complete data were not available for all patients with the two drugs.

\section{Results}

Effects on plasma PTH concentrations-The mean plasma concentration of PTH was $0 \cdot 44 \pm 0 \cdot 12 \mu \mathrm{g} / \mathrm{l}$ before the administration of propranolol and $0.53 \pm 0.23 \mu \mathrm{g} / \mathrm{l}$ before the administration of metoprolol. This difference was not significant. Fig 1 shows the percentage changes in the plasma PTH concentrations after administration of the drugs. After propranolol there was a significant fall $(p<0.02)$ of $54+19 \%$ at 15 minutes and $46+15 \%$ at 30 minutes, whereas there was no significant change at any time after metoprolol, the greatest decrease being $22 \pm 27 \%$ at 60 minutes.

Effects on plasma calcitonin concentrations-The mean plasma concentration of calcitonin was $0.24 \pm 0.05 \mu \mathrm{g} / 1$ before the administration of propranolol and $0 \cdot 19 \pm 0.04 \mu \mathrm{g} / \mathrm{l}$ before the administration of metoprolol. This difference was not significant. Fig 2 shows the percentage changes in plasma calcitonin concentrations after administration of the drugs. After propranolol there was a significant decrease of $26 \pm 10 \%$ at 15 minutes $(p<0.02)$ and $18 \pm 15 \%$ at 60 minutes $(p<0.05)$. With metoprolol there was no significant 'change at any time. The difference between the two drugs was significant at 60 minutes.

Effects on other indices of calcium phosphate metabolism-There were no significant changes after either propranolol or metoprolol in plasma $\mathrm{pH}$ or concentrations of total and ionised calcium, phosphate, protein, or bicarbonate. No difference was observed between the two drugs.

Effects on heart rate-The heart rate was stable before the administration of both drugs, and both induced a similar significant decrease in heart rate.

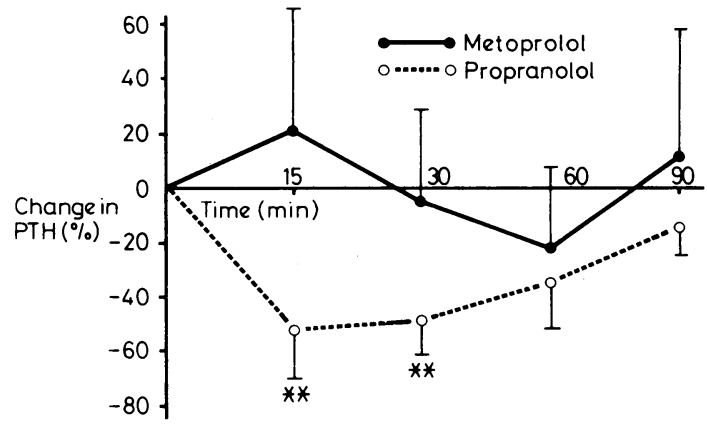

FIG 1-Percentage change in PTH concentration ( \pm SEM) after administration of propranolol and metoprolol. ${ }^{* *} p<0.02$, significance of difference from pre-treatment value.

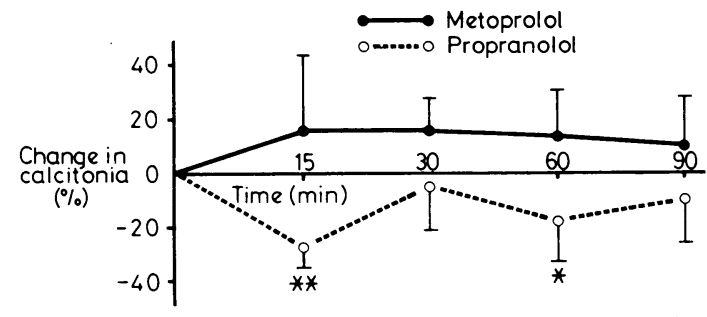

FIG 2-Percentage change in calcitonin concentration \pm SEM $)$ after admin
$* 00.05, * * p<0.02$

\section{Discussion}

Despite the fact that all patients had moderate to severe renal failure, the mean plasma concentrations of PTH before administration of the drugs were only at the upper limit of normal. This finding is well known when PTH concentrations are measured with an N-terminal specific antibody, whereas they are consistently well above the upper limit of normal when they are measured with a C-terminal specific antibody. ${ }^{22}$ Nevertheless, only $\mathrm{N}$-terminal specific radioimmunoassay can detect sharp decreases in plasma concentrations because of the shorter half lives of the $\mathrm{N}$-terminal fragments and of the native molecule that are measured with this assay. We therefore chose an N-terminal specific radioimmunoassay to study the changes in plasma PTH concentrations during the 90 minutes after the intravenous administration of beta-blocking agents.

Our data show that when propranolol and metoprolol were given at doses that induce the same degree of beta-receptor blockade, as assessed by fall in heart rate, propranolol but not metoprolol suppressed PTH secretion whereas plasma ionised calcium remained constant. This agrees with the in-vitro demonstration by Aurbach ${ }^{4}$ that only $\beta_{2}$-adrenoreceptors are found on parathyroid cells and that their blockade decreases PTH secretion. Similarly, the fact that plasma concentrations of calcitonin were significantly decreased by propranolol and not by metoprolol suggests also that calcitonin secretion is modulated by $\beta_{2}$-adrenergic receptors. This agrees with the finding of $\mathrm{Hsu}$ and Cooper that salbutamol, a specific $\beta_{2}$-adrenoreceptor stimulating agent, stimulates calcitonin secretion.

Since propranolol reduces plasma PTH concentrations in the short term, studies to assess its long-term effect on PTH secretion in uraemic patients with hypertension resistant to volume depletion and to compare this long-term effect with that of other antihypertensive drugs such as the cardioselective beta-blockers clonidine and methyldopa are warranted. No such 
prospective studies have been done, although they are necessary to assess the clinical relevance of our findings. In a recent study ${ }^{23}$ we compared metoprolol, clonidine, and methyldopa for six weeks in 13 patients undergoing haemodialysis and we found no significant difference between the three drugs in plasma concentrations of PTH, calcitonin, and phosphate. Plasma calcium concentrations were, however, significantly higher with clonidine than with metoprolol, suggesting a relatively greater suppression of PTH secretion with metoprolol. In their recent preliminary communication, Caro et $a l^{24}$ found that patients on long-term haemodialysis treated with propranolol had lower plasma concentrations of PTH and alkaline phosphatase and a lower incidence of radiological bone disease than patients treated in the same centre but not receiving beta-blockers. Since the doses of dihydrotachysterol and phosphate binders were comparable in both groups ${ }^{25}$ the fact that lower alkaline phosphatase and a lower incidence of radiological bone disease were associated with lower PTH concentrations suggests that the probable simultaneous decrease of calcitonin secretion has no serious harmful effects in spite of the observations of Kanis et al suggesting the contrary. ${ }^{3}$

The study of Caro et al was, however, retrospective and obviously long-term prospective studies are needed to assess the clinical relevance of the additional potential suppression of PTH secretion by propranolol or other non-selective betablockers in preventing or reversing renal osteodystrophy in uraemic patients. If this appears to be important non-selective beta-blockers would then be the drugs of choice to treat hypertension in uraemic men resistant to volume depletion.

\section{References}

1 Fournier A, Vaysse J, Lacombe M. Rein et hypertension artérielle. Possibilités thérapeutiques. Baillères Editeur Paris 1978;75-92.

2 Sebert JL, Fournier A, Gueris J, Marie P, Coevoet B, De Fremont JF, Kuntz D. Ostéodystrophie rénale. Acquisitions physiopathologiques récentes et acquisitions thérapeutiques récentes. Nouv Presse Med $1977 ; 6: 3419-24,3527-33$.

${ }^{3}$ Kanis JA, Earnshaw M, Heynen G, et al. Changes in histologic and biochemical indexes of bone turnover after bilateral nephrectomy in patients on hemodialysis: evidence for a possible role of endogenous calcitonin. N Engl f Med 1977;296:1073-9.

- Aurbach GD, Brown EM, Marx SJ. Receptors and cyclic nucleotides in secretion and action of parathyroid hormone. Calcif Tiss Res 1977; suppl 22, 117-26.

5 Fischer JA, Blum JW, Binswanger U. Acute parathyroid hormone response to epinephrine in vivo. $\mathcal{F}$ Clin Invest 1973;52:2434-40.

${ }^{6}$ Blum JW, Fischer JA, Hunziker WH, Binswanger V, Picotti GB, Daprada M, Guillebeau A. Parathyroid hormone responses to catecholamines and to changes of extracellular calcium in cows. 7 Clin Invest $1978 ; 61: 1113-22$.

7 Kukreja SC, Johnson PA, Ayala G, Banerjee P, Boxser EN, Hargis GK, Williams GA. Role of calcium and betaadrenergic system in control of parathyroid secretion. Proc Soc Exp Biol Med 1976;15:326-8.
${ }^{8}$ Williams GA, Kukreja SC, Baneriee P, Ayala G, Hargis G, Bowser E, Henderson WJ. Effect of beta-adrenergic stimuli on parathyroid secretion in primary and secondary hyperparathyroidism. Clin Res $1975 ; 22: 539$.

Metz S, Deftos L, Baylin KD, Robertson RP. Neuroendocrine modulation of calcitonin and parathyroid hormone secretion in normal man. Clin Res 1977;25:161.

10 Christensen MS, Brandsborg O, Christensen NJ. Inhibition of parathyroid hormone secretion by isoproterenol. In: Massry S, Ritz E, ds. Phosphate metabolism. New York: Plenum Press 1977:363-8.

11 Atkinson RL, Dahms WT. Parathyroid hormone secretion in obese and lean humans: effects of adrenergic stimulus and blockade. Clin Res $1977 ; 25: 102$

12 Kukreja SC, Williams GA, Hargis GK, Bowser EN, Banerjee P, Vora NM, Henderson WJ. Dual control of suppressibility of parathyroid hormone by calcium and by beta-adrenergic blockade. Mineral Electrolyte Metab $1979 ; 2: 316-22$

13 Care AD, Bates RFL, Gitelman HJ. Evidence for a role of cyclic AMP in the release of calcitonin. Ann NY Acad Sci 1971;185:317-26.

14 Bell NH. The effects of glucagon, dibutyryl cyclic $3^{\prime} 5^{\prime}$ adenosine monophosphate and theophylline on calcitonin secretion in vivo. 7 Clin Invest 1970;49:1368-73.

$15 \mathrm{Hsu}$ WH, Cooper CW. Hypercalcemic effect of catecholamines and its prevention by thyrocalcitonin. Calcif Tiss Res 1975;19:125-37.

16 Williams GA, Vora NM, Hargis GK, et al. Parathyroid hormone and calcitonine secretion: comparison of response to calcium and to betaadrenergic system. Sixth Parathyroid Conference. Vancouver, June 1977, abstracts p 44.

17 Heynen G, Cecchettin M, Gaspar S, Kanis J, Franchimont P. The effects of betablockade on ethanol induced secretion of calcitonin in chronic renal failure. Calc Tissue Res 1977;suppl 22:137-41.

18 Andrejak M, Fournier A, Hardin JM, Lambrey G, De Fremont JF, Coevoet B. Les bétabloquants dans le traitement de l'hypertension artérielle. Coeur et Méd Int 1978;17:113-22.

19 Sachs C, Bourdeau AM, Presle V. Ionized calcium measurement in whole blood, a new application of the calcium selective liquide membrane electrode. Eur $\mathcal{F}$ Clin and Biol Res $1971 ; 16: 831-2$.

${ }^{20}$ Desplan C, Jullienne A, Raulais D, Rivaille P, Barlet JP, Mouhktar MS, Milhaud G. Dosage radioimmunologique du fragment biologiquement actif de l'hormone parathyroidienne. Colloque International sur le Radio-immunodosage et les méthodes connexes en Médecine. Berlin, 1977.

21 Moukhtar MS, Jullienne A, Rivaille P, Milhaud G. Dosage radioimmunologique de la calcitonine humaine. In: RadioImmunoassay and related procedures of medicine. Vienna: International Atomic Energy Agency, 1974:379-97.

22 Arnaud CD, Goldsmith RS, Bordier P, Sizemore GW, Larsen JA, Gilkimson J. Influence of immunoheterogeneity of circulating parathyroid hormone on results of radioimmunoassays of serum in man. Am F Med 1974 ;56:785-93.

${ }^{23}$ Coevoet B, De Fremont JF, Andrejak M, et al. Clinical and metabolic effects of antihypertensive drugs in patients on chronic hemodialysis. A cross over trial with metoprolol, alphamethyldopa and Clonidin. In: Yamori Y, Lovenberg W, Fries E, eds. Proceedings of the international symposium on the prophylactic approach to hypertensive disease. New York: Raven Press (in press).

${ }^{24}$ Caro JF, Besarab A, Burke JF, Glemon JA. A possible role for propranolol in the treatment of renal osteodystrophy Lancet 1978;ii:451-3.

${ }^{25}$ Caro JF, Besarab A, Burke JF, Glemon JA. Propranolol for renal osteodystrophy. Lancet $1979 ; \mathrm{i}: 101-2$.

(Accepted 4 March 1980)
ONE HUNDRED YEARS AGO Ruskin long ago called attention to the extraordinary fatigue experienced by visitors to picture galleries, and attributed it partly to the constant alteration of the focus of the eye, and the straining effort to see what is out of sight; and partly to the continual change of temper and thought which the study of a mixed and unclassified exhibition involves. This extraordinary fatigue is very prevalent in London at the present time, being experienced daily by hundreds who pursue their studies at Burlington House, not wisely but too well. And, in many cases, it is not merely excessive weariness of body and mind that is induced by communion with our living artists, but intense frontal headache, sleeplessness, and nervous prostration. The heat of the rooms, the trivial anxieties engendered by hustling one's way through'the crowd, and the effort to shut the ears to the babbling of inanities and crudities around, and to concentrate the attention on what is fair and of good report, contribute to this condition; but that it is mainly due to incessant and violent vaulting from theme to theme will be realised by any person of sensitive habit, who has contrasted the physical and mental effects of studying a miscellaneous collection of pictures like that of the Royal Academy with those produced by the same amount of study expended on a series of connected pictures, with some continuity of idea-as, for instance, those of one master, arranged in chronological order. In the former case, the fatigue incurred is vastly greater than in the latter. Academy headaches are not to be treated by bromide of potassium, or chloral, or quinine, or gelseminum - at least, not without medical supervision; and wine, even when it affords immediate relief, is scarcely a safe remedy to which to resort. They are better avoided than fought off; and those liable to them should indulge but sparingly in aesthetic dissipation. They should visit the Academy only when fresh and vigorous-not when already half worn out - and fortified by a nutrious and digestible meal. They should not attempt more than one hour's study at a time, and should confine their attention to a small number of pictures, not wandering too far either above or below the line; for skied paintings are, by their position and inherent qualities, peculiarly apt to induce headache. The open air should be sought on leaving the gallery, and a cup of soup or coffee will be useful at that time. Recumbency in a darkened room will sometimes remove the headache should it supervene. It should be borne in mind, that the repetition of such headaches again and again is not free from danger. (British Medical fournal, 1880.) 